Naoki Yamada • Tadao Arinami

Kimiko Yamakawa-Kobayashi • Hideki Watanabe

Satoshi Sohda • Hiromi Hamada • Takeshi Kubo

Hideo Hamaguchi

\title{
The $4 \mathrm{G} / 5 \mathrm{G}$ polymorphism of the plasminogen activator inhibitor-1 gene is associated with severe preeclampsia
}

Received: October 14, 1999 / Accepted: January 4, 2000

\begin{abstract}
Preeclampsia is associated with thrombosis of the intervillous or spiral artery. A deletion/insertion polymorphism $(4 \mathrm{G}$ or $5 \mathrm{G}$ ) in the promoter of the plasminogen activator inhibitor type $1(P A I-1)$ gene is suggested to be involved in regulating the synthesis of the inhibitor, $4 \mathrm{G}$ allele, being associated with the enhanced gene expression and plasma PAI-1 levels. We assessed the association between preeclampsia and the $4 \mathrm{G} / 5 \mathrm{G}$ polymorphism of the PAI-1 gene in 115 preeclamptic patients, 210 pregnant controls, and 298 healthy volunteer controls. The frequency of the homozygotes for the $4 \mathrm{G}$ allele was significantly higher in the patients than in the control pregnant women $(P=0.04)$ or in the healthy volunteers $(P=$ $0.02)$. The $4 \mathrm{G}$ allele frequency was also significantly higher in the patients than in the control group of pregnant women $(P=0.03)$ and in the healthy volunteers $(P=0.02)$. These results suggest that the presence of the $4 \mathrm{G} / 4 \mathrm{G}$ genotype of the $P A I-1$ gene is one of the risk factors for preeclampsia.
\end{abstract}

Key words Preeclampsia $\cdot$ Plasminogen activator inhibitor type $1 \cdot$ Gene $\cdot$ Polymorphism

\section{Introduction}

Severe preeclampsia contributes to maternal and fetal morbidity and mortality. Causal factors include environmental and inherited components. Although the pathogenesis of preeclampsia is not well understood, intervillous or spiral artery thrombosis and inadequate placental perfusion are associated with severe preeclampsia (Dekker and Sibai

N. Yamada $(\varangle) \cdot$ H. Watanabe $\cdot$ S. Sohda $\cdot$ H. Hamada $\cdot$ T. Kubo Department of Obstetrics and Gynecology, Institute of Clinical Medicine, University of Tsukuba, 1-1-1 Tennodai, Tsukuba, Ibaraki 305-8575, Japan

Tel. +81-298-53-3352; Fax +81-298-53-3333

e-mail: md965409@md.tsukuba.ac.jp

T. Arinami · K. Yamakawa-Kobayashi · H. Hamaguchi Department of Medical Genetics, Institute of Basic Medical Sciences, University of Tsukuba, Tsukuba Japan
1998).

Plasminogen activator inhibitor-1 (PAI-1) is a major inhibitor of fibrinolysis. A central step in the fibrinolytic process is the conversion of plasminogen to plasmin, which is regulated by such activators as tissue-type plasminogen activator (t-PA) and urokinase-type plasminogen activator (u-PA). PAI-1, which is a fast-acting inhibitor of t-PA, regulates the rate of clot dissolution (Pannekoek et al. 1986). A significant elevation of plasma and placental PAI-1 levels has been found in pregnant woman with severe preeclampsia as compared with levels in normal pregnant women (Estelles et al. 1989; Reith et al. 1993). A decrease in plasma fibrolytic activity caused by increased PAI-1 levels has also been reported in preeclampsia (Estelles et al. 1989; Caron et al. 1991; Estelles et al. 1994).

The PAI-1 gene, which contains nine exons and is distributed over approximately $12.3 \mathrm{~kb}$, has been localized to q21.3-q22 of chromosome 7 (Klinger et al. 1987; Follo and Ginsburg 1989; Bosma et al. 1988). A common single guanosine insertion/deletion polymorphism (4G/5G polymorphism) in the promoter region of the PAI-1 gene, situated 675 base pairs upstream from the transcriptional start site, was recently identified. In-vitro assays of promoter activity demonstrated that the $4 \mathrm{G}$ allele had a significantly higher activity than the $5 \mathrm{G}$ allele (Dawson et al. 1993). The polymorphism was associated with plasma PAI-1 activity in vivo. Plasma PAI-1 activity is higher in individuals homozygous for the $4 \mathrm{G}$ allele than in those who are heterozygous or homozygous for the 5G allele (Dawson et al. 1993; Eriksson et al. 1995; Ye et al. 1995; Ossei-Gerning et al. 1997). An increase in the frequency of the $4 \mathrm{G} / 4 \mathrm{G}$ genotype has been reported in young men with myocardial infarction (Eriksson et al. 1995), in patients with non-insulin dependent diabetes mellitus who have a history of ischemic heart disease (Mansfield et al. 1995), and in patients with coronary atheroma and a previous myocardial infarction (OsseiGerning et al. 1997). In contrast, no difference in genotype distribution was observed between the patients and the control subjects in the ECTIM (Etude Cas-Temoins de I'Infarctus du Myocarde) study (Ye et al. 1995).

We have hypothesized that the $4 \mathrm{G}$ allele of the $4 \mathrm{G} / 5 \mathrm{G}$ 
polymorphism in the promoter region of the $P A I-1$ gene is a genetic risk factor for preeclampsia. In the present study, we examined the association between preeclampsia and the $4 \mathrm{G}$ allele of the polymorphism in a retrospective case-control design.

\section{Subjects and methods}

Subjects

All subjects studied were unrelated Japanese individuals. There were 115 preeclamptic patients, 210 pregnant controls, and 298 healthy volunteer controls. The preeclamptic patients ( $n=115$; aged 20-43 years) were those who were managed at the University of Tsukuba Hospital. The diagnosis of preeclampsia was based on the criteria of the American College of Obstetricians and Gynecologists (ACOG 1990). Severe preeclampsia was defined as a systolic blood pressure of $\geqq 160 \mathrm{mmHg}$ and/or a diastolic blood pressure of $\geqq 110 \mathrm{mmHg}$, with proteinuria. None of the subjects had a history of hypertension, of diabetic nephropathy, or of other renal disease. The pregnant control women (aged 20-43 years), who had delivered at greater than 22 weeks of gestation at the University of Tsukuba Hospital, were 126 primiparous and 84 multiparous women. They had not had hypertension or proteinuria during the pregnancy. None of the control multiparous women had had a history of preeclampsia in a previous pregnancy. The profiles of these subjects are shown in Table 1. The patients with preeclampsia had a higher mean body mass index (BMI) than the pregnant controls at admission for delivery. A greater percentage of the patients with preeclampsia had a family history of hypertension compared with the pregnant controls. Obesity and a family history of hypertension are well known risk factors for preeclampsia.

In addition, to assess the frequencies of the allele of the $4 \mathrm{G} / 5 \mathrm{G}$ polymorphism of the $P A I-1$ gene in Japanese individuals, we genotyped a panel of 298 healthy volunteers who were recruited at their annual health examinations, performed at the Tsuchiura Kyodo General Hospital. They were unrelated normotensive Japanese adults (79\% male; mean age, $51.4 \pm 7.7$ years). The Ethics Committee of Tsukuba University approved the protocol of this study,

Table 1. Profiles of cases and pregnant controls

\begin{tabular}{|c|c|c|c|}
\hline & $\begin{array}{l}\text { Patients with } \\
\text { preeclampsia } \\
n=115\end{array}$ & $\begin{array}{l}\text { Controls } \\
n=210\end{array}$ & $P$ \\
\hline Age (years) & $31.2 \pm 5.2$ & $31.2 \pm 4.8$ & NS \\
\hline Primiparous/multiparous & $66 / 39$ & $126 / 84$ & NS \\
\hline BMI before conception & $22.1 \pm 3.1$ & $21.4 \pm 3.5$ & NS \\
\hline $\begin{array}{l}\text { BMI at admisson for } \\
\text { delivery }\end{array}$ & $26.5 \pm 3.6$ & $25.5 \pm 3.0$ & 0.01 \\
\hline Family history $(\%)^{\mathrm{a}}$ & 49.6 & 21.9 & 0.000006 \\
\hline
\end{tabular}

BMI, Body mass index

${ }^{a}$ Percentage of subjects whose parents or siblings had a history of hypertension and written informed consent for participation was obtained from each subject before blood was sampled.

Methods

Genomic DNA was isolated from peripheral blood leukocytes by the phenol-extraction method. Genotypes for the $4 \mathrm{G} / 5 \mathrm{G}$ polymorphism of the $P A I-1$ gene were determined using the polymerase chain reaction-restricted fragment length polymorphism (PCR-RFLP) method, according to Margaglione et al. (1997).

\section{Statistical analysis}

Hardy-Weinberg equilibrium was tested by a $\chi^{2}$ test with one degree of freedom (DF) separately in cases and controls. Allele frequencies were deduced from the genotype frequencies, and the difference between cases and controls was tested by a $\chi^{2}$ test with one DF. Genotype distributions for $4 \mathrm{G} / 4 \mathrm{G}$ vs $4 \mathrm{G} / 5 \mathrm{G}+5 \mathrm{G} / 5 \mathrm{G}$ were also compared between cases and controls by a $\chi^{2}$ test. A level of $P<0.05$ was accepted as significant.

\section{Results}

The distribution of genotypes of the $4 \mathrm{G} / 5 \mathrm{G}$ polymorphism of the $P A I-1$ gene is shown in Table 2 . The frequency of the $4 \mathrm{G} / 4 \mathrm{G}, 4 \mathrm{G} / 5 \mathrm{G}, 5 \mathrm{G} / 5 \mathrm{G}$ genotypes was $0.60,0.32$, and 0.08 , respectively, in the patients with preeclampsia; 0.48, 0.40, and 0.12 , respectively, in the pregnant control subjects; and $0.47,0.41$, and 0.12 , respectively, in the healthy volunteers. The observed number of genotypes in the three groups did not differ significantly from those that would be expected from the Hardy-Weinberg equilibrium. The frequency of individuals homozygous for the $4 \mathrm{G}$ allele was significantly higher in the patients than in the pregnant control group $(P$ $=0.04)$ or in the healthy volunteers $(P=0.02)$. Compared with the pregnant controls, the odds ratio for the risk of preeclampsia associated with the $4 \mathrm{G} / 4 \mathrm{G}$ genotype was 1.62 (95\% confidence interval [CI], 1.02-2.57). The frequency of the $4 \mathrm{G} / 5 \mathrm{G}$ polymorphism of the $P A I-1$ gene is shown in Table 3. The frequency of the $4 \mathrm{G}$ allele was significantly higher in the patients with preeclampsia than in either the control group of pregnant women $(P=0.03)$ or the healthy volunteers $(P=0.02)$. The odds ratio for the risk of preeclampsia associated with the $4 \mathrm{G}$ allele was 1.49 (95\% CI, 1.03-2.15). The armitage linearity tendency test showed the gene dose effect of the $4 \mathrm{G}$ allele $(P=0.02)$.

\section{Discussion}

The present study suggests an association between the $4 \mathrm{G}$ allele of the $4 \mathrm{G} / 5 \mathrm{G}$ polymorphism of the $P A I-1$ gene and the development of preeclampsia. To our knowledge, this is the first such report. The $4 \mathrm{G}$ allele frequency was higher in 
Table 2. Genotype distribution of the $4 \mathrm{G} / 5 \mathrm{G}$ polymorphism of the $P A I-1$ gene

\begin{tabular}{llccrrr}
\hline & $n$ & $4 \mathrm{G} / 4 \mathrm{G}$ & $4 \mathrm{G} / 5 \mathrm{G}$ & $5 \mathrm{G} / 5 \mathrm{G}$ & $P^{*}$ & OR (95\% CI)* \\
\hline Patients with preeclampsia & 115 & $69(0.60)^{\mathrm{a}}$ & $37(0.32)^{\mathrm{a}}$ & $9(0.08)^{\mathrm{a}}$ & - & - \\
Pregnant controls & 210 & $101(0.48)$ & $84(0.40)$ & $25(0.12)$ & 0.04 & $1.62(1.02-2.57)$ \\
Volunteer controls & 298 & $140(0.47)$ & $122(0.41)$ & $36(0.12)$ & 0.02 & $1.67(1.08-2.59)$ \\
Total controls & 508 & $241(0.47)$ & $206(0.41)$ & $61(0.12)$ & 0.02 & $1.66(1.10-2.51)$ \\
\hline
\end{tabular}

* $4 \mathrm{G} / 4 \mathrm{G}$ vs $4 \mathrm{G} / 5 \mathrm{G}+5 \mathrm{G} / 5 \mathrm{G}$

OR, Odds ratio; CI, confidence interval

${ }^{\text {a }}$ Frequency is shown in parentheses

Table 3. Allele frequency of the $4 \mathrm{G} / 5 \mathrm{G}$ polymorphism of the PAI-1 gene

\begin{tabular}{llllll}
\hline & $n$ & $4 \mathrm{G}$ & $5 \mathrm{G}$ & $P$ & OR $(95 \% \mathrm{CI})$ \\
\hline $\begin{array}{l}\text { Patients with } \\
\quad \text { preeclampsia }\end{array}$ & 115 & 0.76 & 0.24 & - & - \\
$\begin{array}{l}\text { Pregnant controls } \\
\text { Volunteer controls }\end{array}$ & 210 & 0.68 & 0.32 & 0.03 & $1.49(1.03-2.15)$ \\
Total controls & 508 & 0.67 & 0.33 & 0.02 & $1.53(1.08-2.17)$ \\
& & & 0.32 & 0.01 & $1.51(1.09-2.11)$ \\
\hline
\end{tabular}

the Japanese control population than in Caucasians (Ye et al. 1995; Ossei-Gerning et al. 1997; Burzotta et al. 1998; Mannucci et al. 1997). This discrepancy may be due to fundamental genetic differences between Japanese and Caucasians.

Increased plasma levels of total plasminogen activator inhibitor (PAI) activity in preeclampsia have been noted for more than a decade (Wiman et al. 1984; de Boer et al. 1988; Gilabert et al. 1990). Plasma total PAI activity is mostly PAI-1 activity. Estelles et al. (1989) and Reith et al. (1993) reported increased plasma PAI-1 activity in hypertensive pregnant women. Although we did not assess PAI1 activity in our subjects, our observation suggests that the increased plasma levels of PAI-1 in the patient with preeclampsia is, at least in part, genetically influenced by the $P A I-1$ gene polymorphism, and that the $4 \mathrm{G}$ allele of the $P A I-1$ gene may be one of the genetic risk factors for preeclampsia. However, as the genotypic and allelic differences between cases and controls were marginally significant in this study, confirming the association in independent populations is warranted.

To date, two thrombophilic mutations have been reported to be associated with an increased risk of preeclampsia. The resistance to activated protein $\mathrm{C}$ caused by an adenine-to-guanine mutation at nucleotide 506 in the factor $\mathrm{V}$ gene (so-called Leiden mutation) is associated with an increased risk of preeclampsia (Dizon-Townson et al. 1996). Homozygosity for the $\mathrm{T}$ allele of the C677T polymorphism in the methylentetrahydrofolate reductase (MTHFR) gene was also reported to be associated with an increased risk of preeclampsia (Sohda et al. 1997). The present study reports the third thrombophilic mutation to be associated with an increased risk of preeclampsia. Therefore, it is hypothesized that the presence of thrombophilic mutations constitutes a genetic predisposition to preeclampsia.

Acknowledgments This work was supported by grants from the Kanzawa Medical Research Foundation and the Ministry of Educa- tion, Science, Sports, and Culture of Japan.

\section{References}

American College of Obstetricians and Gynecologists (1990) National High Blood Pressure Education Program Working Group Report on High Blood Pressure in Pregnancy [see comments]. Am J Obstet Gynecol 163:1691-1712

Bosma PJ, van den Berg EA, Kooistra T, Siemieniak DR, Slightom JL (1988) Human plasminogen activator inhibitor-1 gene. Promoter and structural gene nucleotide sequences. J Biol Chem 263:91299141

Burzotta F, Di Castelnuovo A, Amore C, D’Orazio A, Di Bitondo R, Donati MB, Iacoviello L (1998) 4G/5G promoter PAI-1 gene polymorphism is associated with plasmatic PAI-1 activity in Italians: a model of gene-environment interaction. Thromb Haemost 79:354358

Caron C, Goudemand J, Marey A, Beague D, Ducroux G, Drouvin F (1991) Are haemostatic and fibrinolytic parameters predictors of preeclampsia in pregnancy-associated hypertension? Thromb Haemost 66:410-414

Dawson SJ, Wiman B, Hamsten A, Green F, Humphries S, Henney AM (1993) The two allele sequences of a common polymorphism in the promoter of the plasminogen activator inhibitor-1 (PAI-1) gene respond differently to interleukin-1 in HepG2 cells. J Biol Chem 268:10739-10745

de Boer K, Lecander I, ten Cate JW, Borm JJ, Treffers PE (1988) Placental-type plasminogen activator inhibitor in preeclampsia. Am J Obstet Gynecol 158:518-522

Dekker GA, Sibai BM (1998) Etiology and pathogenesis of preeclampsia - current concepts [Review]. Am J Obstet Gynecol 179:13591375

Dizon-Townson DS, Nelson LM, Easton K, Ward K (1996) The factor $\mathrm{V}$ Leiden mutation may predispose women to severe preeclampsia. Am J Obstet Gynecol 175:902-905

Eriksson P, Kallin B, van 't Hooft FM, Bavenholm P, Hamsten A (1995) Allele-specific increase in basal transcription of the plasminogen-activator inhibitor 1 gene is associated with myocardial infarction. Proc Nat Acad Sci USA 92:1851-1855

Estelles A, Gilabert J, Aznar J, Loskutoff DJ, Schleef RR (1989) Changes in the plasma levels of type 1 and type 2 plasminogen activator inhibitors in normal pregnancy and in patients with severe preeclampsia. Blood 74:1332-1338

Estelles A, Gilabert J, Keeton M, Eguchi Y, Aznar J, Grancha S, Espna F, Loskutoff DJ, Schleef RR (1994) Altered expression of plasminogen activator inhibitor type 1 in placentas from pregnant women with preeclampsia and/or intrauterine fetal growth retardation. Blood 84:143-150

Follo M, Ginsburg D (1989) Structure and expression of the human gene encoding plasminogen activator inhibitor, PAI-1. Gene 84:447453

Gilabert J, Estelles A, Aznar J, Espana F, Andres C, Santos T, Valles J (1990) Contribution of platelets to increased plasminogen activator inhibitor type 1 in severe preeclampsia. Thromb Haemost 63:361366

Klinger KW, Winqvist R, Riccio A, Andreasen PA, Sartorio R, Nielsen LS, Stuart N, Stanislovitis P, Watkins P, Douglas R, Grzeschik KH, Alitaro K, Blasi, Dano K (1987) Plasminogen activator inhibitor type 1 gene is located at region $\mathrm{q} 21.3-\mathrm{q} 22$ of chromosome 7 and geneti- 
cally linked with cystic fibrosis. Proc Nat Acad Sci USA 84:85488552

Mannucci PM, Mari D, Merati G, Peyvandi F, Tagliabue L, Sacchi E, Taioli E, Sansoni P, Bertolini S, Franceschi C (1997) Gene polymorphisms predicting high plasma levels of coagulation and fibrinolysis proteins. A study in centenarians. Arterioscler Thromb Vasc Biol 17:755-759

Mansfield MW, Stickland MH, Grant PJ (1995) Plasminogen activator inhibitor-1 (PAI-1) promoter polymorphism and coronary artery disease in non-insulin-dependent diabetes. Thromb Haemost 74:1032-1034

Margaglione M, Grandone E, Cappucci G, Colaizzo D, Giuliani N, Vecchione G, d'Addedda M, Di Minno G (1997) An alternative method for PAI-1 promoter polymorphism (4G/5G) typing (letter). Thromb Haemost 77:605-606

Ossei-Gerning N, Mansfield MW, Stickland MH, Wilson IJ, Grant PJ (1997) Plasminogen activator inhibitor-1 promoter 4G/5G genotype and plasma levels in relation to a history of myocardial infarction in patients characterized by coronary angiography. Arterioscler Thromb Vasc Biol 17:33-37

Pannekoek H, Veerman H, Lambers H, Diergaarde P, Verweij CL, van Zonneveld AJ, van Mourik JA (1986) Endothelial plasminogen activator inhibitor (PAI): a new member of the Serpin gene family. EMBO J 5:2539-2544

Reith A, Booth NA, Moore NR, Cruickshank DJ, Bennett B (1993) Plasminogen activator inhibitors (PAI-1 and PAI-2) in normal pregnancies, pre-eclampsia and hydatidiform mole. $\mathrm{Br} \mathrm{J}$ Obstet Gynaecol 100:370-374

Sohda S, Arinami T, Hamada H, Yamada N, Hamaguchi H, Kubo T (1997) Methylenetetrahydrofolate reductase polymorphism and preeclampsia. J Med Genet 34:525-526

Wiman B, Csemiczky G, Marsk L, Robbe H (1984) The fast inhibitor of tissue plasminogen activator in plasma during pregnancy. Thromb Haemost 52:124-126

Ye S, Green FR, Scarabin PY, Nicaud V, Bara L, Dawson SJ, Humphries SE, Evans A, Luc G, Cambou JP, Arveiler D, Henney AM, Cambien F (1995) The 4G/5G genetic polymorphism in the promoter of the plasminogen activator inhibitor-1 (PAI-1) gene is associated with differences in plasma PAI-1 activity but not with risk of myocardial infarction in the ECTIM study. Thromb Haemost 74:837-841 